\title{
Superficial Methane Emissions from a Landfill in Merida, Yucatan, Mexico
}

\author{
Emisiones superficiales de metano en un relleno sanitario \\ en Mérida, Yucatán, México
}

\author{
Sauri-Riancho María Rosa \\ Facultad de Ingeniería \\ Universidad Autónoma de Yucatán \\ E-mail:sriancho@uady.mx \\ Stentiford Edward I. \\ School of Civil Engineering, UK \\ Faculty of Engineering \\ University of Leeds \\ E-mail:e.i.stentiford@leeds.ac.uk \\ Gamboa-Marrufo Mauricio \\ Facultad de Ingeniería \\ Universidad Autónoma de Yucatán \\ E-mail:gmarrufo@uady.mx
}

\author{
Reza-Bacelis Gabriela \\ Facultad de Ingeniería \\ Universidad Autónoma de Yucatán \\ E-mail:gabriela.reza@proactiva.com.mx \\ Cahuich-Poot Nayla \\ Facultad de Ingeniería \\ Universidad Autónoma de Yucatán \\ E-mail:nayre63@hotmail.com \\ Méndez-Novelo Roger \\ Facultad de Ingeniería, México \\ Universidad Autónoma de Yucatán \\ E-mail:mnovelo@uady.mx
}

Information on the article: received: September 2010, reevaluated: October 2011 and August 2012, accepted: February 2013

\begin{abstract}
On worldwide scale, one of the most important anthropogenic methane sources is landfill disposal for solid wastes. The main goal of this work was to quantify methane emissions at one landfill built in Merida, Mexico. This site had venting wells by which a passive control for biogas movement was exerted. At the venting wells, methane concentrations were measured monthly during a 6 months period, Methane surface emission rate was estimated with the close chamber technique. Obtained results indicated that there are both spatial and seasonal variations in biogas composition. The average methane value during the monitoring period was $21.9 \%$ (12.7 to $32.5 \mathrm{~V} / \mathrm{V})$ and the surface flow rate was in the range of 0 to $6,004 \mathrm{~g} \mathrm{CH}_{4} \mathrm{~m}^{-2} \mathrm{~d}^{-1}$, with an average value of $1,480 \mathrm{~g} \mathrm{CH}_{4} \mathrm{~m}^{-2} \mathrm{~d}^{-1}$, which is a high value in respect to these reported in publications.
\end{abstract}

\section{Keywords:}

- methane emissions

- landfill gas

- greenhouse gases

- solid waste disposal

- landfills 


\section{Resumen}

Entre las fuentes antropogénicas más importantes de metano a escala mundial se encuentra la disposición final de los residuos sólidos. El objetivo de este trabajo fue cuantificar las emisiones de metano provenientes de un relleno sanitario en Mérida, México, en el que el movimiento del biogás se controlaba pasivamente utilizando pozos de venteo. Las concentraciones de metano se midieron mensualmente en los pozos de venteo del sitio a lo largo de un período de 6 meses. La tasa de emisión superficial de metano se determinó utilizando la técnica de cámara cerrada. Los resultados indicaron que existen variaciones considerables tanto espaciales como estacionales de la composición del biogás proveniente de los pozos de venteo con un promedio de concentración de metano en el sitio, durante todo el periodo de monitoreo, de 21.9\% (12.7 a $32.5 \mathrm{~V} / \mathrm{V})$. Los flujos superficiales de gas medidos en diversos puntos a lo largo de la superficie del relleno sanitario tuvieron un promedio de 1,480 $\mathrm{g} \mathrm{CH}_{4} \mathrm{~m}^{-2} \mathrm{~d}^{-1}$, lo que se consideró un valor muy alto cuando se comparó con la información hallada en la literatura. El intervalo registrado fue de 0 a $6,004 \mathrm{~g} \mathrm{CH}_{4} \mathrm{~m}^{-2} d^{-1}$.

\section{Introduction}

Solid waste management systems make a significant contribution to greenhouse gases (GHGs) emissions. During collection, transport and incineration $\mathrm{CO}_{2}$ emissions take place, also landfills and open dumps are considered as one of the most important sources of global methane (Börjesson et al., 1998; Börjesson, 2001; Humer and Lechner, 1999a; Bogner et al., 1995). It is estimated that $\mathrm{CH}_{4}$ emitted from landfills contributes approximately $10 \%$ to the annual increase in the atmospheric content (Reeburgh, 1996). Some 40 to 60 million tonnes of methane are annually generated in landfills and old dumps worldwide. These releases are caused by inadequate landfill gas collection systems, gas extraction measures carried out in the framework of aftercare programmes at old contaminated sites and landfills, and uncontrolled emissions from unauthorized open dumping grounds (Humer and Lechner, 1999b). Globally, if $50 \%$ of the low-estimate for emissions from landfills were captured, this would amount to about $20 \%$ of the global total annual high-end estimate of the methane increment (Milich, 1999). The best method to stop methane emission from landfills is to undertake landfill gas (LFG) recovery with associated gas use, but even in landfills with gas collection systems, part of the produced biogas is lost into the atmosphere. The quantity still exploitable is only around $70 \%$ of the total production even with the best gas management systems (Manna et al., 1999).

In developing countries (DC), open dumps are still being used as the final disposal method for solid waste. Many DCs have legislation in place, which is intended to change this method of final disposal. Due to its simplicity, sanitary landfill is the option that has been considered to replace the dump sites, but this method could have a high impact in terms of carbon emissions. Nowadays, landfill methane emissions are estimated using computer programmes that use constants based on information from developed countries; this is why, it is important to have actual landfill methane emissions data from particular sites, given that there is a lack of field figures about this topic from developing countries.

Barton et al. (2008) considered six waste disposal options that might be suitable for developing countries. In their analysis of options, the worst case in terms of carbon emissions, even worse than open dumping, was landfilling without either gas flaring or electricity production. The two best options were composting and anaerobic digestion with energy production and composting of the digestate.

In Mexico, urban solid waste disposal is regulated by the NOM-083-SEMARNAT-2003, which establishes the specifications for environmental protection of the site. These specifications include: site selection, design, construction, operation, monitoring, closure and complementary works at a site for final disposal of urban solid wastes and wastes requiring special handling. This Mexican Official Norm categorizes the sites according to the tonnes of wastes that enter every day, as shown in Table 1 (SEMARNAT, 2004). The differences between the classes of disposal sites are the requirements with which they have to comply. Sites type D do not have to control biogas emissions. Sites type A and B must estimate the quantity of generation of biogas ta- 
king into account the chemical composition of the wastes to be handled. Sites A, B and C have to extract, capture, transmit, and control the biogas generated in the final disposal site. Therefore, the first task is to estimate the amount of methane to be produced and/or emitted at a disposal site.

Table 1. Classification of urban solid waste disposal sites in Mexico

\begin{tabular}{cc}
\hline TYPE & Waste received (tonnes/day) \\
\hline A & Greater than 100 \\
B & 50 to 100 \\
C & 10 and less than 50 \\
D & Less than 10 \\
\hline
\end{tabular}

Source: NOM-083-SEMARNAT-2003 (SEMARNAT 2004)

This study was performed at a landfill in Merida, Yucatan, in the southeast part of Mexico. The State of Yucatan is located in the centre part of the Yucatan peninsula, which is a large limestone platform and forms the northern part of the Gulf Coastal Plain Province of Mexico (Escolero et al., 2000). It is classified as a Karstic region characterized by an almost flat platform, mainly made up of limestone that is very permeable. The latitude of Yucatan is between $21^{\circ} 36^{\prime}$ and $19^{\circ} 32^{\prime}$ and its longitude between $87^{\circ} 32^{\prime}$ and $90^{\circ} 25^{\prime}$. It occupies a total area of $39,612 \mathrm{~km}^{2}$ representing $2 \%$ of the total surface of Mexico. Yucatan has a total population just over 1.8 million inhabitants. Merida is the largest city of the state with a population of around 850,000 inhabitants (INEGI, 2007).

The first data on solid waste generation in Yucatan are from 1980, when it was estimated that 5 cities in Yucatan had a per capita generation of $0.24-0.25 \mathrm{~kg} /$ $\mathrm{ca} / \mathrm{d}$. Nowadays, the true figures are unknown. Official figures are based on collection volumes that are not really measured, but estimated. Taking into consideration that collection system coverage is also unknown in the communities of Yucatan, these figures could be highly imprecise. According to the last statistics of the state, 1,432.2 tonnes per day are collected from houses (INEGI, 2005); therefore, the estimated average per capita household waste generation is 0.8 $\mathrm{kg} / \mathrm{ca} / \mathrm{d}$. Solid waste generated in Yucatan during 2005 represented only $1.4 \%$ of the total generation in Mexico (INEGI, 2005).

The last national survey, performed in 2005, stated that solid waste disposal sites occupy 179.4 ha in Yucatan, of which 134.4 ha were operated as "open dumps", without any control. The remaining 45 ha were: a sanitary landfill, which is the Merida site (19 ha), and ap- proximately 20 "controlled fills" or, according to the NOM-083-SEMARNAT-2003, the first one is classified as a site type A, and the 20 others as sites type D (INEGI, 2005).

The Merida landfill began operating late in November 1997 and it receives the municipal solid waste that is collected from the city of Mérida. The landfill is trapezoidal in cross-section with a maximum height of $30 \mathrm{~m}$. When the landfill is completed, the wastes will occupy a total area of 18.77 ha divided into 8 cells. From November-1997 to February-2007 approximately $1,850,000$ tonnes of waste were deposited in 6 cells, which represented an average waste input of around 540 tonnes/day.

On this site, the area method is used for landfilling with the majority of the waste being contained above ground level. This landfilling method is used because a feature of this area is the high groundwater level. The landfill was built with a double geomembrane layer system underneath and leachate is collected at the bottom of each cell, pumped to evaporation ponds, and then recirculated through the cells, especially during the dry season. Due to lack of soil in the region, a non consolidated calcite known locally as sahcab is used as daily and intermediate cover. Completed slopes have been isolated putting a geomembrane (synthetic liner) on top of the fill material in order to contain gas emissions and avoid rainfall infiltration and therefore, minimize leachate volume.

At the time of the study, the landfill did not have a gas extraction system. The movement of LFG was controlled by means of passive method, using venting wells, which were built up progressively from the bottom of the landfill through to the final landfill cover. In the management of the landfill, generally 2 vents / ha were included giving a total of 32, up to February 2007 (Figure 1). Landfill gas was just released to the atmosphere, but the company that operated the landfill was planning to install some burners, in order to meet Mexican legislation standards (SEMARNAT, 2004) and obtain carbon credits.

The results reported in this paper are from this $\mathrm{Me}-$ rida landfill site. The first part of the study looked at the LFG composition through the venting wells and the second part, due to the specific characteristics of the venting wells which were not suitable to measure LFG flow, estimated the methane emission solely through the landfill cover. Furthermore, on this last topic a literature synthesis is presented in Table 2, including values obtained by authors using the same close chamber methodology on disposal sites with different climatic and operational conditions. 


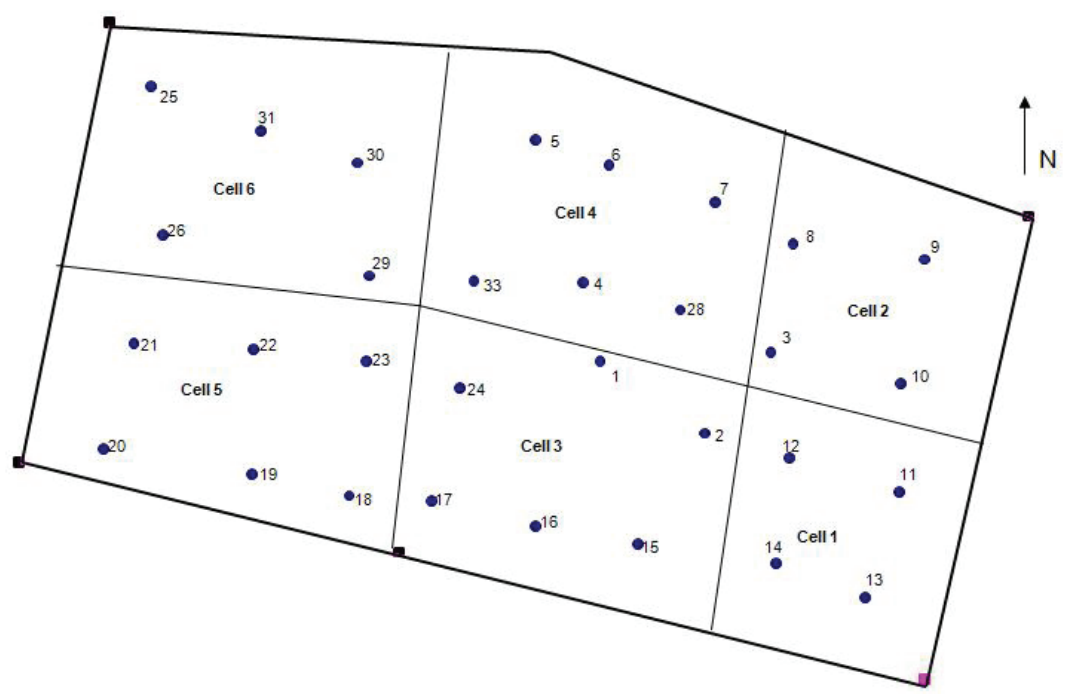

Figure 1. Plan showing the location of the venting wells in each of the cells of the Merida landfill

Table 2. Summary of some similar studies found in literature

\begin{tabular}{|c|c|c|c|c|c|c|}
\hline Ref./ Site & $\begin{array}{l}\text { Waste } \\
\text { Age } \\
\text { (year) }\end{array}$ & $\begin{array}{l}\text { Yearly } \\
\text { Waste } \\
\text { Inputs } \\
\text { (ktons) }\end{array}$ & $\begin{array}{l}\text { Surface } \\
\text { (ha) }\end{array}$ & Cover & $\begin{array}{c}\text { LFG } \\
\text { management }\end{array}$ & $\begin{array}{l}\text { Flux } \\
\left(\mathrm{g} \mathrm{CH}_{4} \mathrm{~m}^{-2} \mathrm{~d}^{-1}\right)\end{array}$ \\
\hline \multicolumn{7}{|c|}{ Åkerman et al. (2007): } \\
\hline $\begin{array}{l}\text { Site A } \\
\text { UK }\end{array}$ & $0-40$ & 515 & 110 & Clay $(1 \mathrm{~m})$ and geomembrane & $\begin{array}{l}\text { two gas turbine engines and } \\
\text { one steam turbine engine }\end{array}$ & 2.04 \\
\hline $\begin{array}{l}\text { Site B } \\
\text { UK }\end{array}$ & $4-24$ & 220 & 13 & $\begin{array}{l}\text { Compacted soil }(1-2 \mathrm{~m}) \\
\text { and vegetation }\end{array}$ & $\begin{array}{l}\text { two gas turbine engines } \\
\text { each of } 1 \mathrm{MW}\end{array}$ & 0.24 \\
\hline $\begin{array}{l}\text { Site C } \\
\text { UK }\end{array}$ & $1-7$ & 185 & 8 & $\begin{array}{l}\text { Bottom ashes }(1 \mathrm{~m}) \text { and } \\
\text { clay or limestone }(0.3 \mathrm{~m})\end{array}$ & 2 flares $\left(2000\right.$ and $\left.500 \mathrm{~m}^{3} / \mathrm{h}\right)$ & 10.7 \\
\hline $\begin{array}{l}\text { Site D } \\
\text { UK }\end{array}$ & $1-7$ & 130 & 8 & Clay $(0.5-0.7 \mathrm{~m})$ & 1 flare $\left(2000 \mathrm{~m}^{3} / \mathrm{h}\right)$ & 16.8 \\
\hline $\begin{array}{l}\text { Site E } \\
\text { UK }\end{array}$ & $1-38$ & 80 & 15 & Clay $(0.5-1 \mathrm{~m})+$ soil & 1 flare $\left(2000 \mathrm{~m}^{3} / \mathrm{h}\right)$ & 6.5 \\
\hline \multicolumn{7}{|c|}{ Abichou et al. (2006) } \\
\hline Florida, USA & 1 & - & $64^{*}$ & $\begin{array}{l}15 \mathrm{~cm} \text { thick non-vegetated } \\
\text { intermediate cover (sandy clay) }\end{array}$ & - & 54 \\
\hline Florida, USA & 7 & - & $60.8^{*}$ & $\begin{array}{l}45 \mathrm{~cm} \text { thick vegetated intermediate } \\
\text { cover (sandy clay and sandy loam) }\end{array}$ & - & 22 \\
\hline $\begin{array}{l}\text { Czepiel et al. } \\
\qquad(2003) \\
\text { New } \\
\text { Hampshire, } \\
\text { USA }\end{array}$ & $0-26$ & 287 & 60 & $1-2 \mathrm{~m}$ of sandy clay loam & $\begin{array}{l}\text { Internal combustion } \\
\text { generators and flared }\end{array}$ & $12.3-44.5$ \\
\hline $\begin{array}{c}\text { I-Chu C.et al. } \\
\text { (2007) } \\
\text { Taipei, } \\
\text { Taiwan }\end{array}$ & $26-36$ & 1168 & $\begin{array}{c}37 \\
\text { (test area }= \\
32 \text { ha) }\end{array}$ & $\begin{array}{l}1-2 \mathrm{~m} \text { of waste landfill soil covered } \\
\text { with } 1-1.5 \mathrm{~m} \text { of loam-clay loam } \\
\text { soil and was reconstructed as a } \\
\text { recreational park in 2001. It is } \\
\text { vegetated }\end{array}$ & $\begin{array}{l}\text { Gas extraction system. The } \\
\text { recovered } \mathrm{CH}_{4} \text { was burned. }\end{array}$ & $-0002-3.9$ \\
\hline
\end{tabular}




\section{Materials and methods}

As stated before, this study, and thus its methodology, is divided in two parts: the first one, to measure the LFG composition through venting wells, and the second part, to estimate the methane emission solely through the landfill cover.

\section{Gas quality in venting wells}

Figure 1 shows the location of the venting wells in each of the 6 Cells of the landfill. Cell numbers were assigned according the order they began to be built; Cell 1 was the first cell of the landfill, and Cell 6 was the last. The first layer of wastes in Cell 6 was deposited in January 2005.

In order to assess the quality of the LFG produced in the Merida landfill, methane concentrations were measured once a month in the venting wells of the site, from September 2004 to April 2005. There were 26 venting wells when the study began and 32 at the end of the monitoring period. Only 20 venting wells could be monitored throughout the monitoring campaign, those on cells 1 to 4 , minus two of them that were inaccessible, plus two situated in Cell 5; the other six remaining venting wells were situated in this cell, but in areas which were under construction during the sampling period. The venting wells that were in the landfill working area could not be monitored throughout the whole sampling period. The venting wells were numbered in the same order in which they were randomly located using a global positioning system (GPS). Each of the venting wells was covered with an impervious sheet during the monitoring day. The Gas Analyser LANDTEC GEM$500 \AA$ was used to make the readings in the field. The equipment was factory calibrated at CES-Landtec facilities prior to the experiments and a field calibration was performed each day before monitoring, according to the Gem-500 Operation Manual (CES-Landtec, 1998).

In order to show methane concentrations distribution in the landfill area, a geospatial analysis was performed for methane concentration obtained each month in each venting well. The kriging method was used. In kriging, a model of the overall spatial measured variance structure is used to generate the interpolated contours. The measured variance structure is shown as a variogram with half of the variance on the $y$-axis and sample separation distance on the $\mathrm{x}$-axis. Key variables for a variogram are the nugget (unexplained or error variance), sill (total model variance, equal to nugget plus "scale"), and range (distance where the variance reaches the sill) (Yates and Warrick, 2002). The software GS+ (Geostatistics for the Environmental Science) version 5.1.1 was used to obtain the best variogram to fit the data and Golden Software Surfer 8 was fed with this variogram to get the isoconcentration curves.

\section{Methane emission rates}

Methane emission rates from the landfill surface were determined using a static chamber technique, which is the one most frequently used for measuring gas fluxes from soils. The principle of the static chamber is to seal a known volume above a gas-emitting or consuming surface such that the emitted (or consumed) gas cannot escape and its accumulation in the volume can be monitored (Abichou et al., 2006). The chamber used in this study was constructed with polyethylene and had a diameter of $64 \mathrm{~cm}$ (covering an area of $0.322 \mathrm{~m}^{2}$ ). The chamber was sealed around the sides at ground level by firming soil around the outside. It contained a small fan to circulate air inside the chamber (Figure 2). Methane was measured with a CES-LANDTEC@ GEM-500 gas meter after sealing (time 0 ) and at regular time intervals for 15 - $20 \mathrm{~min}$ (once in each of the monitoring sites). Measurements were taken over the landfill surface which was not sealed with surface geomembrane. Methane flux was determined from concentration data, $C$ (in ppmv), plotted versus elapsed time, $t$ (in minutes). The data generally fit a linear relationship, in which case $d C / d t$ is the slope of the fitted line. The methane flux, $F\left(\mathrm{~g} / \mathrm{m}^{2} / \mathrm{d}\right)$, was then calculated using equation 1 (Abichou et al., 2006).

$F=P^{*} V^{*} M^{*} U^{*}(d C / d t) /\left(A^{*} T^{*} R\right)$

where $P$ is the pressure (atm), $V$ is the chamber volume (93.6 L), $M$ is the molar mass of methane $(16 \mathrm{~g} / \mathrm{mol}), U$ is the units conversion factor $\left(0.00144 \mathrm{~L} \mathrm{~min} \mu \mathrm{L}^{-1} \mathrm{~d}^{-1}\right), A$ is the area covered by the chamber $\left(0.322 \mathrm{~m}^{2}\right), T$ is the chamber temperature $(\mathrm{K})$, and $R$ is the gas constant (0.08205 L atm K $\left.\mathrm{mol}^{-1}\right)$.

The data would be considered acceptable for estimating the gas flux rate if the following criteria were met (EA, 2004):

- $\quad \mathrm{r}^{2}>0.8(\mathrm{r}$, correlation coefficient - line fitting parameter);

- The graph had more than five data points; and

- There was a measurable change in concentration. 


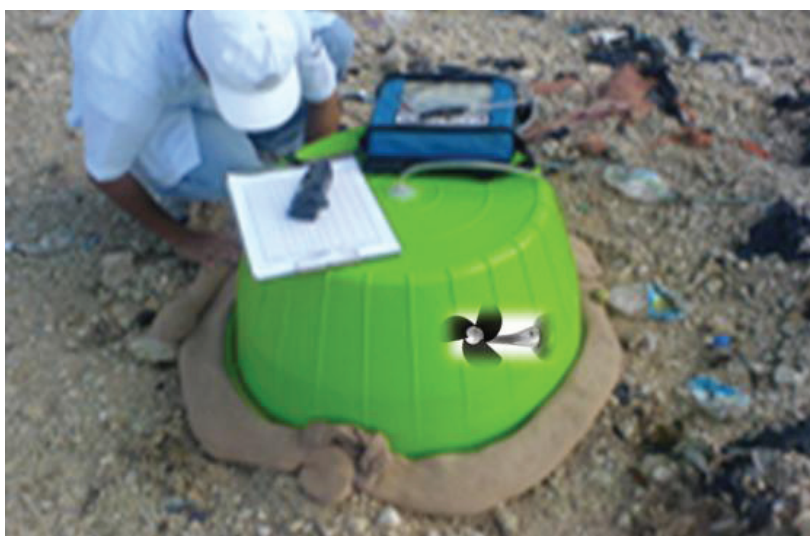

Figure 2. Static chamber technique applied in Merida landfill

Thirty monitoring sites were selected according to the methodology recommended by the UK Environment Agency (EA, 2004). All the monitoring sites were located with a GPS. In order to measure superficial emissions, the monitoring sites had to be located in cells without the final cover that considers a synthetic layer; therefore, four of them were situated close to the working front (cells 5 and 6), in places with intermediate landfill cover; two were on top of the recently finished cells 3 and 4, with no synthetic cover layer, and the others were over the slopes and the temporary roads, in cells 5 and 6 , in places where it was thought gas could be emitted. A plan of the monitoring sites is shown in Figure 3.

\section{Results and discussion}

Gas quality in venting wells

Eight plots were obtained from the geospatial analysis, one per month of the monitoring period; they are presented in Figure 4. It can be observed that methane concentrations fell down from December to January and the distribution of this gas in the landfill varied considerably. Figure 4 shows that methane emissions in the venting wells varied over all the landfill both spatially and temporarily. This coincides with other studies in which such variation has been observed (Spokas et al., 2006; Abichou et al., 2006; Gebert and Groengroeft, 2006). Due to the specific characteristics of the venting wells, which were not suitable to measure LFG flow and the lack of suitable equipment, the methane flow rate in the venting wells could not be measured at the time of the study.

Table 3 shows the summary of the average results obtained monthly in each cell from September 2004 to April 2005. The numbers assigned to the cells are in the order that they were built; Cell 1 was the first cell of the landfill, and cell 6 was the last. The first layer of wastes was deposited in cell 6 in January 2005.

Methane concentrations were higher during the rainy season (Sept-Dec) than those obtained during the dry season (Jan-Apr). Although excess of humidity might decrease the production of methane, probably the typical high temperatures of the region during the rainy season caused the increment of these values shown, not only in Table 3, but also in Figure 4, which was obtained using a geospatial analysis with the kriging method.

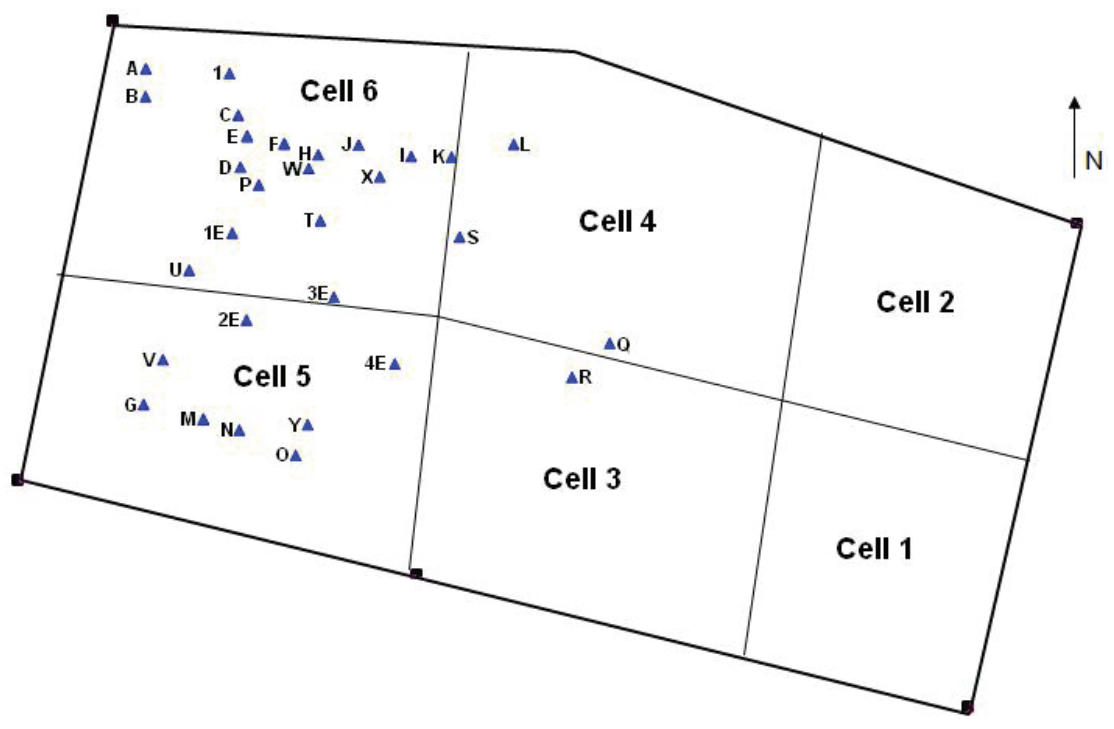

Figure 3. Location of surface emission rate monitoring sites 


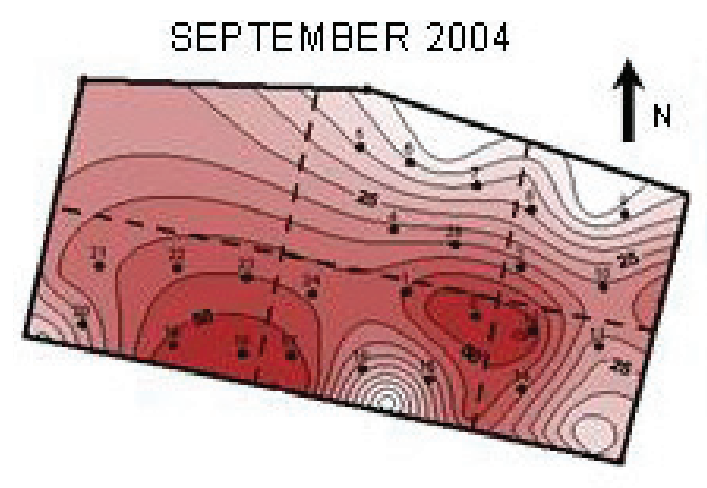

OCTOBER 2004

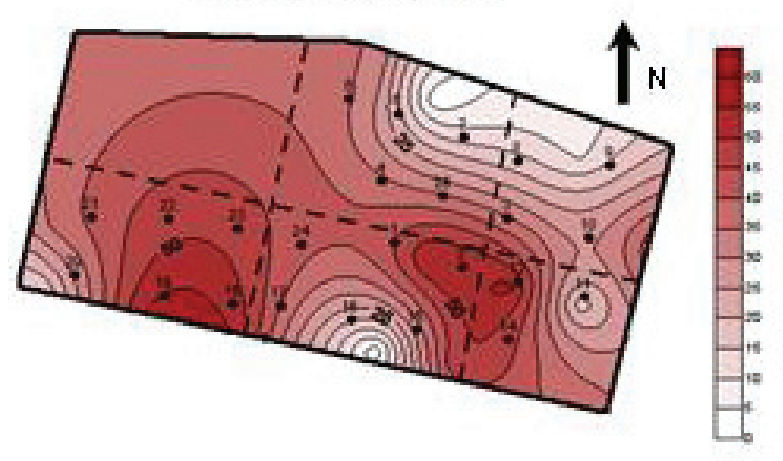

NOVEMBER 2004

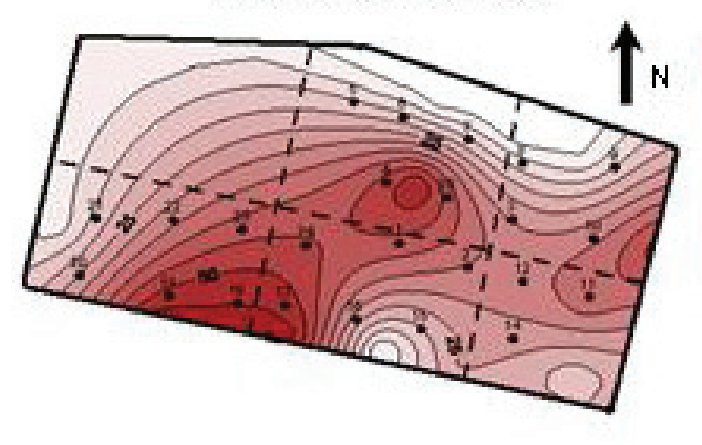

DECEM BER 2004

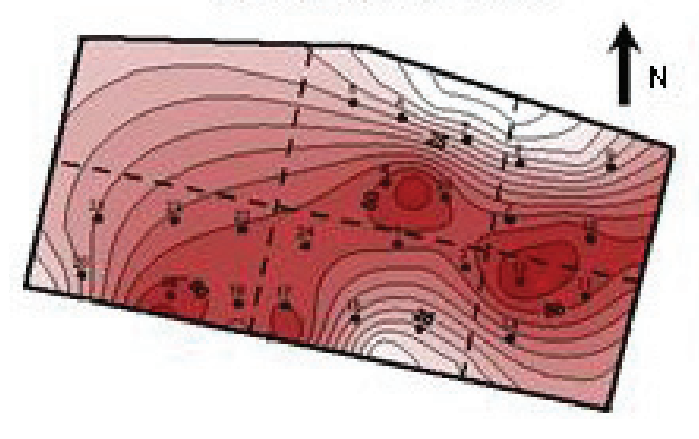

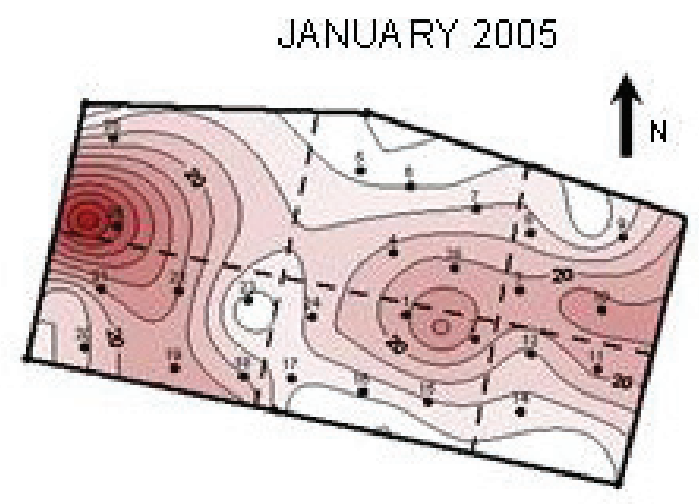

FEBRUARY 2005
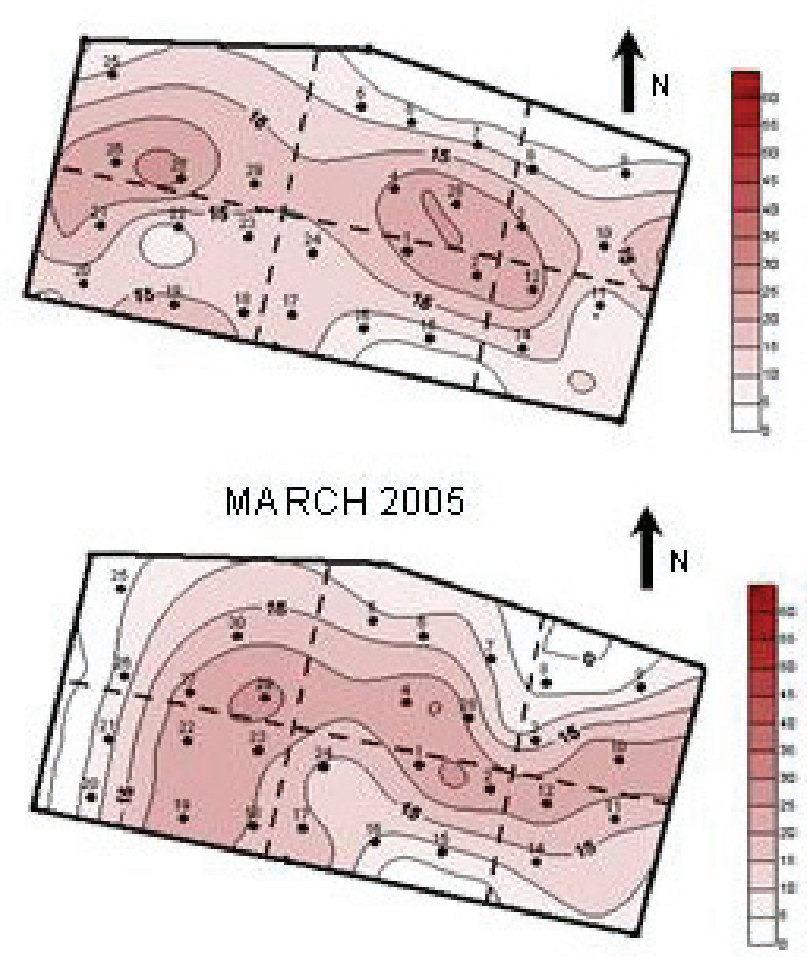

APRIL 2005

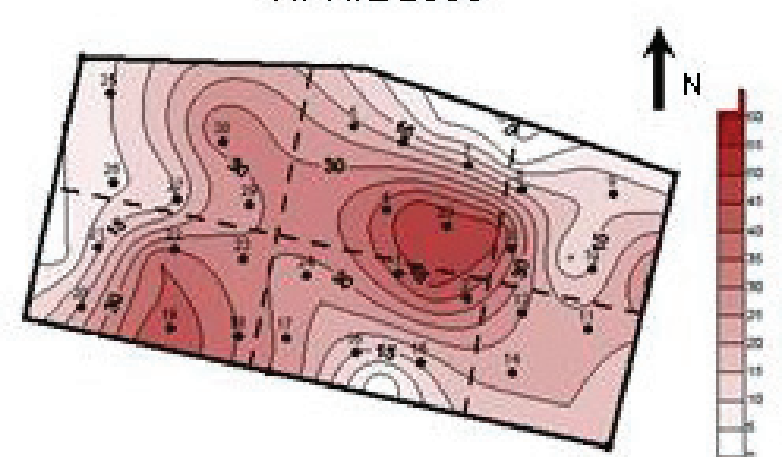

Figure 4. Curves of isoconcentration of methane (in \% by volume) at the Merida landfill 
Table 3. Summary of the results obtained for the methane concentration in the venting wells (average per cell) at the Merida landfill (Sept 04 - Apr 05)

\begin{tabular}{|c|c|c|c|c|c|c|c|c|c|c|c|c|}
\hline \multirow{2}{*}{ CELL } & \multicolumn{12}{|c|}{ Methane concentration ( $\%$ by volume) } \\
\hline & SEP & OCT & $\mathrm{NOV}$ & DEC & JAN & FEB & MAR & APR & MEAN & STD & MAX* & $\mathrm{MIN}^{*}$ \\
\hline 1 & 21.9 & 29.2 & 27.7 & 36.7 & 13.7 & 8.3 & 11.5 & 18.8 & 21.0 & 9.8 & 50.0 & 1.0 \\
\hline 2 & 20.3 & 27.9 & 28.3 & 38.5 & 20.3 & 12.2 & 15.5 & 16.9 & 22.6 & 8.6 & 53.3 & 0.1 \\
\hline 3 & 42.6 & 39.0 & 28.6 & 35.3 & 10.8 & 12.4 & 14.0 & 23.3 & 24.4 & 12.6 & 60.0 & 0.0 \\
\hline 4 & 7.9 & 15.2 & 16.4 & 18.6 & 7.7 & 11.4 & 10.0 & 24.1 & 16.9 & 5.7 & 60.2 & 0.0 \\
\hline 5 & 38.2 & 40.4 & 36.1 & 33.9 & 15.8 & 13.7 & 14.8 & 28.5 & 24.8 & 11.2 & 59.6 & 0.0 \\
\hline 6 & & & & & 31.5 & 18.5 & 12.2 & 17.2 & 21.6 & 8.2 & 60.4 & 0.5 \\
\hline MEAN & 29.9 & 31.6 & 27.3 & 32.5 & 15.0 & 12.7 & 13.1 & 22.1 & 21.9 & 9.4 & 57.3 & 0.3 \\
\hline STD & 21.6 & 19.1 & 21.4 & 21.3 & 14.3 & 9.0 & 9.7 & 15.5 & 17.8 & & & \\
\hline MAX & 55.9 & 57.5 & 58.0 & 60.2 & 60.4 & 28.6 & 27.2 & 49.7 & 53.4 & & & \\
\hline $\mathrm{MIN}^{*}$ & 0 & 1.3 & 0.1 & 1.0 & 0 & 0.8 & 0.0 & 0.0 & 0.5 & & & \\
\hline
\end{tabular}

* Maximum and minimum individual sampling values

\section{Surface flux measurement}

Surface flux results obtained during the monitoring period showed that from the 30 points measured on the surface of the landfill and presented in Figure 3, twenty were emitting methane. Results from the calculation of superficial methane emission flux are presented in Table 4 . The data were considered to be acceptable for estimating the gas flux rate using the criteria suggested by the United Kingdom Environmental Agency (EA, 2004).

After eliminating individual data points, only 18 were left meeting UK-EA criteria which were listed in the section of Materials and Methods. In the two eliminated points, $1 \mathrm{E}$ and $\mathrm{Y}$, the data was used to give a rough estimate of the gas escaping from that particular area of landfill surface even though the data did not satisfy these criteria. Results are shown in Figure 5 where their locations are grouped in intervals of methane concentration $\left(\mathrm{g} \mathrm{CH}_{4} \mathrm{~m}^{-2} \mathrm{~d}^{-1}\right)$.

On the methane superficial emission sampling area there were two distinguishable zones where gas was being emitted at a high rate (Figure 5), one in the north eastern part, at $15 \mathrm{~m}$ above the ground, approximately, in cell 6, and the other one, at the south eastern part of the landfill, in cell 5, also at the same height; due to the high methane emissions obtained from some monitoring locations $(\mathrm{E}, \mathrm{F}$ and $\mathrm{M})$, new readings were taken in these points. The purpose of this part of the study was to get an estimate of the methane flux based on punctual measurements to find zones where more methane was escaping; also, to compare the emission rates with other sites under different climatic and operational conditions.

Specific characteristics of the studied disposal sites and the $\mathrm{CH}_{4}$ superficial emissions detected in some of those found in literature are summarized in Table 2. Superficial emissions at the Merida landfill were very high compared with values found in the literature (Table 2). Abichou et al. (2006) reported arithmetic mean fluxes of 54 and $22 \mathrm{~g} \mathrm{CH}_{4} \mathrm{~m}^{-2} \mathrm{~d}^{-1}$ from 2 different types of intermediate covers in 2 areas of a landfill in Florida (the thin cover, $15 \mathrm{~cm}$ thick-non-vegetated, and the thick cover, $45 \mathrm{~cm}$ thick-vegetated). They reported peak fluxes of 596 and $330 \mathrm{~g} \mathrm{CH}_{4} \mathrm{~m}^{-2} \mathrm{~d}^{-1}$ for the thin and the thick cover respectively. Spokas et al. (2006) reported $\mathrm{CH}_{4}$ emission rates ranging from 0.0022 to $10 \mathrm{~g} \mathrm{CH}_{4}$ $\mathrm{m}^{-2} \mathrm{~d}^{-1}$. Hilger and Humer (2003) detected fluxes of about $840 \mathrm{~L} \mathrm{CH}_{4} \mathrm{~m}^{-2} \mathrm{~d}^{-1}\left(600 \mathrm{~g} \mathrm{CH}_{4} \mathrm{~m}^{-2} \mathrm{~d}^{-1}\right)$ and Chu et al. (2007) from -0.1 to $163.3 \mathrm{mg} \mathrm{CH}_{4} \mathrm{~m}^{-2} \mathrm{~h}^{-1}$ (-0.002 to $3.9 \mathrm{~g}$ $\mathrm{CH}_{4} \mathrm{~m}^{-2} \mathrm{~d}^{-1}$ ). Akerman et al. (2007) conducted methane emission measurements on five landfills with different characteristics and gas management strategies. The average values they found ranged from 0.032 to $16.8 \mathrm{~g}$ $\mathrm{CH}_{4} \mathrm{~m}^{-2} \mathrm{~d}^{-1}$, but they found values up to $308 \mathrm{~g} \mathrm{CH}_{4} \mathrm{~m}^{-2}$ $\mathrm{d}^{-1}$ on slopes, and from 1 to $38 \mathrm{~g} \mathrm{CH}_{4} \mathrm{~m}^{-2} \mathrm{~d}^{-1}$, at operating zones. 
Table 4. Methane emission estimates - the letters refer to locations shown in figure 3

\begin{tabular}{|c|c|c|c|}
\hline Point & $r^{2}$ & $\begin{array}{l}\text { No. of } \\
\text { Obs. }\end{array}$ & $\mathrm{gCH}_{4} \mathrm{~m}^{-2} \mathrm{~d}^{-}$ \\
\hline $1 \mathrm{E}$ & 0.9243 & 3 & 3,231 \\
\hline $\mathrm{E}$ & 0.9499 & 10 & 3,806 \\
\hline E & 0.963 & 8 & 4,778 \\
\hline E & 0.9906 & 8 & 3,150 \\
\hline F & 0.9038 & 8 & 648 \\
\hline $\mathrm{F}$ & 0.9707 & 8 & 2,016 \\
\hline $\mathrm{H}$ & 0.8178 & 6 & 2,265 \\
\hline I & 0.9833 & 8 & 318 \\
\hline $\mathrm{J}$ & 0.8835 & 8 & 2,492 \\
\hline $\mathrm{K}$ & 0.8116 & 8 & 2,023 \\
\hline $\mathrm{L}$ & 0.9601 & 8 & 496 \\
\hline G & 0.9969 & 8 & 3,142 \\
\hline M & 0.8723 & 8 & 6,004 \\
\hline M & 0.8785 & 5 & 4,391 \\
\hline $\mathrm{N}$ & 0.8177 & 7 & 529 \\
\hline $\mathrm{O}$ & 0.8685 & 8 & 3,041 \\
\hline $\mathrm{P}$ & 0.8303 & 5 & 30 \\
\hline S & 0.9081 & 6 & 32 \\
\hline $\mathrm{T}$ & 0.8599 & 6 & 84 \\
\hline $\mathrm{U}$ & 0.8816 & 7 & 661 \\
\hline $\mathrm{V}$ & 0.9153 & 8 & 1,248 \\
\hline $\mathrm{W}$ & 0.8011 & 7 & 401 \\
\hline$x$ & 0.8437 & 4 & 13,731 \\
\hline Y & 0.8938 & 4 & 945 \\
\hline
\end{tabular}

It can be seen that almost all the $\mathrm{CH}_{4}$ superficial emissions values found in the literature have been performed on sites with a cover material containing clay. It should also be noted that, except the values reported by Akerman et al. (2007), all the other values are from sites having cover material of at least $1 \mathrm{~m}$ thick. Also, all of them extract LFG (there is no data on Abichou et al., 2006).

No field data on surface methane emissions at landfills from Latin America were found. The Merida site values, with an average flux of $1,484 \mathrm{~g} \mathrm{CH}_{4} \mathrm{~m}^{-2} \mathrm{~d}^{-1}$ (STD = $1,750 \mathrm{~g} \mathrm{CH}_{4} \mathrm{~m}^{-2} \mathrm{~d}^{-1}$ ) and a maximum of $6004 \mathrm{~g} \mathrm{CH}_{4} \mathrm{~m}^{-2}$ $\mathrm{d}^{-1}$ (considering only the 18 locations where more than 5 points were taken for the linear correlation, $\mathrm{r}^{2}>0.8$ ), are very high compared with values reported in literature. Point $\mathrm{X}$ reported the highest value of $13,731 \mathrm{~g} \mathrm{CH}_{4} \mathrm{~m}^{-2}$ $\mathrm{d}^{-1}$, but it did not meet criteria to be considered (Table 4). Nevertheless, that point could be considered as a point emissions location; according to Bogner et al. (1997), point emissions of landfill $\mathrm{CH}_{4}$ can vary over seven orders of magnitude, from 0.0004 to $4,000 \mathrm{~g} \mathrm{CH}_{4} \mathrm{~m}^{-2} \mathrm{~d}^{-1}$. Points $\mathrm{M}$ and $\mathrm{X}$ values are much higher.

The Merida landfill $\mathrm{CH}_{4}$ emission values could be explained by the particular characteristics of the disposal site involving factors such as:

- the method of operation (land area with leachate recirculation),

- the gas management strategy (up to October 2007 it was passively vented to the atmosphere),

- the material used as daily and intermediate cover, which was inorganic (non consolidated calcite),
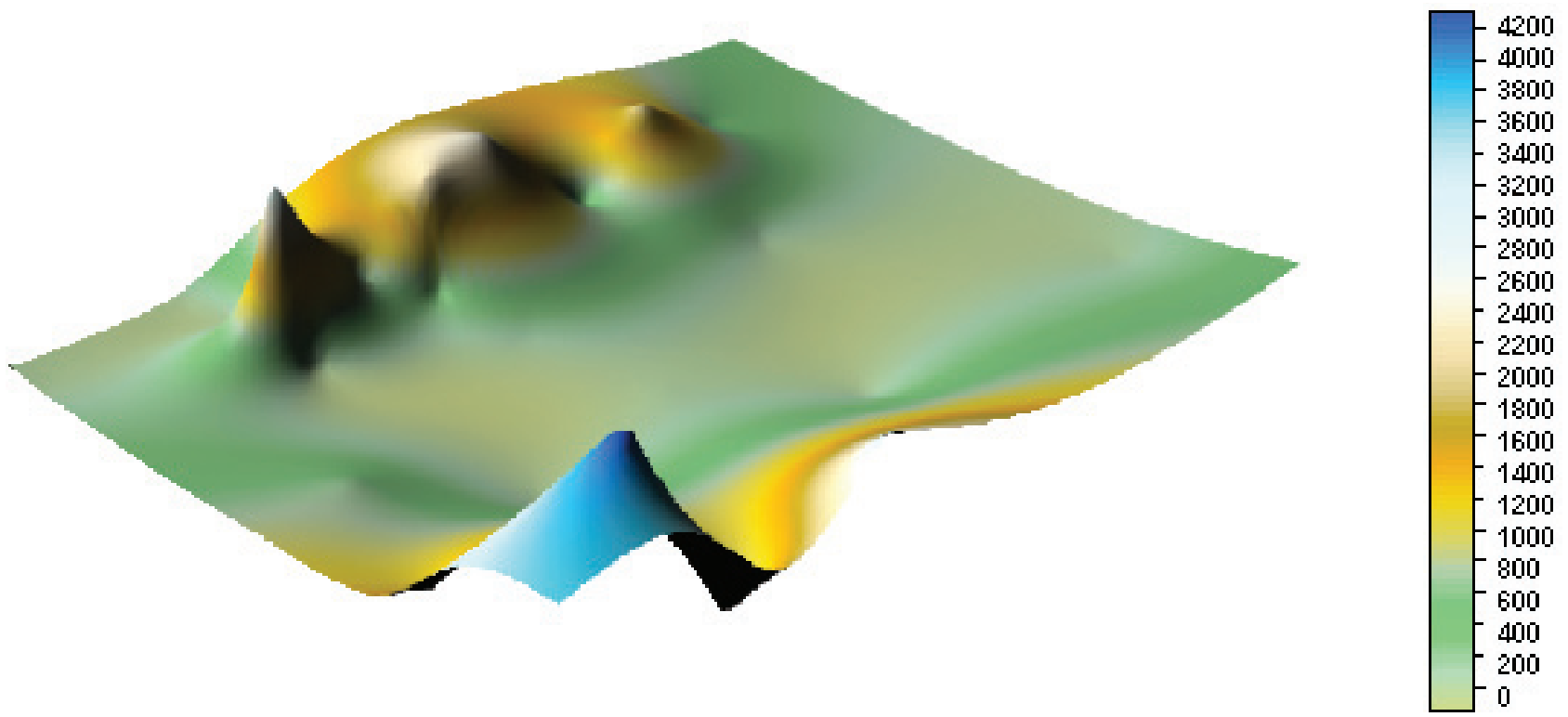

Figure 5. Distribution of methane superficial emissions $\left(\mathrm{g} \mathrm{CH}_{4} \mathrm{~m}^{-2} \mathrm{~d}^{-1}\right)$ detected in the landfill of Merida, Mexico 
- the thickness of the cover (maximum of $0.15 \mathrm{~m}$ ),

- the characteristics of the incoming wastes which are mainly organic ( $>40 \%$ by weight) and

- the climate, with high temperatures all year long and a total precipitation rate close to $1,000 \mathrm{~mm} /$ year.

It also has to be taken into account that, before performing superficial gas measurements, the landfill was oversaturated due to previous heavy rainfall (194.2 $\mathrm{mm})$. Therefore, leachate from upper layers could be seen coming out in some places; this could force gas to escape through some specific zones, in this case, those previously described.

\section{Conclusions and further work}

Non uniform LFG emissions in terms of both, composition and flow, were measured at the landfill. Spatial and seasonal variations in LFG composition at the venting wells were found with a total average methane composition across the site of $22 \%(\mathrm{~V} / \mathrm{V})$, varying from $0 \%$ to $60.4 \%$.

The decrement of methane concentration measured from all cells, from December 2004 to January 2005 and the increment from March to April 2005, could be attributed to the seasonal climate change. The spatial variation of methane concentration could be attributed to several factors, which would require additional work in situ and further analysis of the results.

Due to changes in the Mexican legislation, the use of venting wells is no longer permitted in disposal sites types A and B (such as Merida landfill), nevertheless, for the other types, it is necessary to develop a methodology to measure methane emissions from their venting wells.

Superficial gas flow measures had an average of $1,484 \mathrm{~g} \mathrm{CH}_{4} \mathrm{~m}^{-2} \mathrm{~d}^{-1}$ (0 to 6,004 $\mathrm{g} \mathrm{CH}_{4} \mathrm{~m}^{-2} \mathrm{~d}^{-1}$ with a SDV of $1,750 \mathrm{~g} \mathrm{CH}_{4} \mathrm{~m}^{-2} \mathrm{~d}^{-1}$ ) which was considered a very high value when compared with data found in literature; nevertheless, this high value could be attributed to fissures found in the intermediate cover of the landfill, where measurements were carried out.

The intention of this work was to obtain an exploratory instant measurement of the methane emissions through the intermediate cover layer. In order to get an average methane emission rate a monitoring net needs to be designed and installed with continuous measurement equipment in order to find the variations during different times of the day and to be able to take into account the meteorological events.

The results obtained in this study are an important contribution to the knowledge of specific Latin-Ameri- can solid waste disposal. At a time when disposal sites from this geographic area are forced to be changed from open dumps to landfills, it is important to have actual landfill methane emissions data from particular sights, given that there is very little field figures about this topic from developing countries.

The Intergovernmental Panel on Climate Change (IPCC) has developed a methodology to assess the methane emissions from solid waste disposal for national greenhouse gas inventories. This methodology is a good general assessment; nevertheless, it is not useful for particular sites. Thus, it is necessary to have field data from disposal sites in Mexico to improve the general estimations. This work provides information that could be useful for this purpose.

\section{Acknowledgements}

To SETASA, the company which operates the Merida landfill, especially its manager, M. Eng. Luis Fernando Archundia-Cañedo, for letting us use the site for this research.

\section{References}

Abichou T., Chanton J., Powelson D., Fleiger J., Escorianza S. Lei Y., Stern J. Methane Flux and Oxidation at Two Types of Intermediate Landfill Covers. Waste Management, volume 26 (issue 11), 2006: 1305-1312.

Åkerman A., Budka A., Hayward-Higham S., Bour O., Rallu D. Methane Emissions Measurements on Different Landfills. Proceedings Sardinia 2007, on: Eleventh International Waste Management and Landfill Simposium. S. Margherita di Pula, Cagliari, Italy, 1-5 October, 2007.

Barton J.R., Issaias I., Stentiford E.I. Carbon-Making the Right Choice for Waste Management in Developing Countries. Waste Management, volume 28, 2008: 690-698.

Bogner J., Spokas K., Burton E., Sweeney R., Corona V. Landfills as Atmospheric Methane Sources and Sinks. Chemosphere, volume 31, (issue 9), 1995: 4119-4130.

Bogner J. E., Spokas K.A., Burton E.A. Kinetics of Methane Oxidation in a Landfill Cover Soil: Temporal Variations, a WholeLandfill Oxidation Experiment, and Modeling of $\mathrm{Net}^{\mathrm{CH}_{4}}$ Emissions. Environmental Science Technology, volume 31, 1997: 2504-2514.

Börjesson G., Sundh I., Tunlid A., Frostegard A., Stevensson B.H. Microbial Oxidation of $\mathrm{CH}_{4}$ at High Partial Pressures in an Organic Landfill Cover Soil Under Different Moisture Regimes. FEMS Microbiology Ecology, volume 26, 1998: 207-217.

Börjesson G. Inhibition of Methane Oxidation by Volatile Sulfur Compounds $\left(\mathrm{CH}_{3} \mathrm{SH}\right.$ and $\left.\mathrm{CS}_{2}\right)$ in Landfill Cover Soils. Waste Management \& Research, volume 19 (issue 4), 2001: 314-319. 
CES-Landtec. Gem-500 Operation Manual, Version 3.32, USA, 1998.

Czepiel P.M., Shorter J.H., Mosher B., Allwine E., McManus J.B., Harriss R.C., Kolb C.E., Lamb B.K. The Influence of Atmospheric Pressure on Landfill Methane Emissions. Waste Management, volume 23, 2003: 593-598.

EA, Environment Agency. Guidance on Monitoring Landfill Gas Surface Emissions, LFTGN 07. Landfill Directive, September 2004, UK.

Escolero O.A., Marin L.E., Steinich B., Pacheco A.J. Delimitation of a Hydrogeological Reserve for a City Within a Karstic Aquifer: the Merida, Yucatan Example. Landscape and Urban Planning, volume 51, 2000: 53-62.

Gebert J., Groengroeft A. Passive Landfill Gas Emission-Influence of Atmospheric Pressure and Implications for the Operation of Methane-Oxidizing Biofilters. Waste Management, volume 26, 2006: 245-251.

Hilger H. and Humer M. Biotic Landfill Cover Treatments for Mitigating Methane Emissions. Environ. Monitoring and Assess, volume 84, 2003: 71-84.

Humer M. and Lechner P. Compost as a Landfill Cover Material for the Elimination of Methane Emissions. Proceedings ORBIT 99, 1999a, pp. 503-510.

Humer M. and Lechner P. Alternative Approach to the Elimination of Greenhouse Gases from Old Landfills. Waste Management E Research, volume 17 (issue 6), 1999b: 443-452.

I-Chu C., Ullas H., Cheng-Hsiung C., Shang-Shyng Y. Methane and Carbon Dioxide Emissions from Closed Landfill in Taiwan. Chemosphere, article in press, 2007.

INEGI, Instituto Nacional de Estadísticas, Geografía e Informática. II Conteo de población y vivienda 2005 [on line]. Date of access: August 4th, 2007. Available on: http:/INEGI.gob.mx.

INEGI, Instituto Nacional de Estadísticas, Geografía e Informática Información geográfica de Yucatán, 2007 [on line]. Date of access: August 4th, 2007. Available on: http:/INEGI.gob.mx.

Manna L., Anetti M.C., Genon G. Modelling Biogas Production at Landfill Site. Resources, Conservation and Recycling, volume 26, 1999: 1-14.

Milich L. The role of Methane in Global Warming: Where Might Mitigation Strategies be Focused? Global Environ. Change, (issue 9), 1999: 179-201.
Reeburg W.S. Soft Spots in the Glogal Methane Budget. Microbial Growth on $\mathrm{C}_{1}$ Compounds, on: Lindstrom M.E. \& Tabita F.R., Dordecht, The Netherlands: Kluwer Academic Publishers, 1996, pp. 334-342. On: Börjersson G. Inhibition of Methane Oxidation by Volatile Sulfur Compounds $\left(\mathrm{CH}_{3} \mathrm{SH}\right.$ and $\left.\mathrm{CS}_{2}\right)$ in Landfill Cover Soils. Waste Management \& Research, volume 19 (issue 4), 2001: 314-319.

SEMARNAT, Secretaría de Medio Ambiente y Recursos Naturales, 2004. NOM-083-SEMARNAT-2003, Especificaciones de protección ambiental para la selección del sitio, diseño, construcción, operación, monitoreo, clausura y obras complementarias de un sitio de disposición final de residuos sólidos urbanos y de manejo especial, Diario Oficial de la Federación, Mexico, October 20, 2004.

Spokas K., Bogner J., Chanton J.P., Morcet M., Aran C., Graff C., Moreau-Le G., Hebe I. Methane Mass Balance at Three Landfill Sites: What is the Efficiency of Capture by Gas Collection Systems? Waste Management, volume 26, (issue 5), 2006: 516525.

Yates S., Warrick A. Geostatistics, 2002, on: Dane J.H., Topp G.C. (Eds). Methods of Soil Analysis, Part 4- Physical Methods. Soil Science Society of America. On: Abichou T., Chanton J., Powelson D., Fleiger J., Escorianza S. Lei Y., Stern J. Methane Flux and Oxidation at Two Types of Intermediate Landfill Covers. Waste Management, volume 26 (issue 11), 2006: 1305-1312.

\section{Citation for this article:}

\section{Chicago citation style}

Sauri-Riancho, María Rosa, Edward I. Stentiford, Mauricio Gamboa-Marrufo, Gabriela Reza-Bacelis, Nayla Cahuich-Poot, Roger Méndez-Novelo. Superficial Methane Emissions from a Landfill in Merida, Yucatan, Mexico. Ingeniería Investigación y Tecnología, XIV, 03 (2013): 299-310.

\section{ISO 690 citation style}

Sauri-Riancho M.R., Stentiford E.I., Gamboa-Marrufo M., RezaBacelis G., Cahuich-Poot N., Méndez-Novelo R. Superficial Methane Emissions from a Landfill in Merida, Yucatan, Mexico. Ingeniería Investigación y Tecnología, volume XIV (issue 3), JulySeptember 2013: 299-310. 


\section{About the authors}

María Rosa Sauri-Riancho. Doctored at the University of Leeds, U.K., she carried out her Master's Degree in Environmental Engineering and her Bachelor's Degree in Chemical Industrial Engineering at the University of Yucatan, Mexico. She is part of the academic staff of the Engineering Faculty of the Autonomous University of Yucatan since 1981. Her research topic is solid waste management as part of the Environmental Engineering academic group. She has publications on solid waste management and leachate treatment and numerous participations in technical conferences.

Edward I. Stentiford. Professor of Public Health Engineering at the University of Leeds, U.K., carried out several degrees studies at the University of Cambridge, U.K. He is member of several Editorial boards of Environmental Journals and has been consultant for government, international agencies, engineering consultants and waste specialist companies. Professor Stentiford has been external examiner for Imperial College and the Open University and has directed numerous Master's and Doctorate thesis. He has many publications on topics such as Waste management in developing countries, Composting process optimization and Determining compost stability.

Mauricio Gamboa-Marrufo. Doctored at the University of Oxford, U.K., he carried out his Master's Degree at the Superior Technical Institute of the Technical University of Lisbon, Portugal; the Informatics Specialty at the Technological Institute of Merida, Mexico, and his Bachelor's Degree in Civil Engineering at the Engineering Faculty of the Autonomous University of Yucatan (FIUADY), Mexico. He is part of the FIUADY Structures and Materials research group since 1991. In 2004 starts the wind engineering research at the FIUADY designing a wind tunnel for the FIUADY Structural and Materials laboratory. He has participated in several multi-disciplinary projects.

Gabriela Reza-Bacelis. She got her Master's Degree in Environmental Engineering at the Engineering Faculty of the Autonomous University of Yucatan, Mexico, and carried out her Bachelor's Degree in Chemical Industrial Engineering at the Technological Institute of Merida, Mexico. She participated as research student in different solid waste research projects and has publications and conference participations in this research topic. Nowadays, she is working for SETASA, the company which operates the Merida, Mexico, Landfill as the Biogas Chief.

Nayla Cahuich-Poot. She got her Master's Degree in Engineering, Environmental Option, at the Engineering Faculty of the Autonomous University of Yucatan, Mexico, and got her Bachelor's Degree in Chemical Industrial Engineer at the Technological Institute of Merida, Mexico. She participated as research student in the landfill emissions characterization project and has participated in technical conferences regarding this topic.

Roger Méndez-Novelo. Doctored at the Technological Institute of Merida, Mexico, he carried out his Master's Degree in Environmental Engineering, Statistics Speciality, Education Speciality and Bachelor's Degree in Civil Engineer at the Autonomous University of Yucatan, Mexico. He is part of the academic staff of the Engineering Faculty of the Autonomous University of Yucatan since 1979. His research topics are wastewater treatment and solid waste management. He belongs to the Environmental Engineering academic group of the Engineering Faculty of the Autonomous University of Yucatan. He has publications on leachate treatment and solid waste management and numerous participations in technical conferences. 